\title{
On the recycling and use of microsilica in the oil industry
}

\author{
$M$. Glazev $^{1}, V$. Bazhin $^{2}$ \\ ${ }^{1}$ Department of Metallurgy, Faculty of Mineral Raw Material Processing, Saint-Petersburg Mining \\ University, Saint-Petersburg, Russia \\ ${ }^{2}$ Department of Automation of Technological Processes and Production, Faculty of Mineral Raw \\ Material Processing, Saint-Petersburg Mining University, Saint-Petersburg, Russia
}

\begin{abstract}
Cementing of casing strings is one of the most important processes of well construction for the exploration and exploitation of oil, gas and gas condensate fields. Despite more than half a century of research and development of grouting mortars, they are not able to provide high strength and good adhesion to the casing string. The article considers the possibility of using microsilica (waste of silicon production) in the oil industry, as an additive of a plugging solution to increase the strength, expansion valve, and reduce the permeability of the plugging stone.
\end{abstract}

\section{Introduction}

The formation, utilization and use of waste currently are one of the most pressing issues in the field of environmental safety and environmental protection both in Russia and worldwide $[1,2,3]$. This is due both to the rapid increase in the volume of production and consumption waste, and to the insufficiently high level of development of the waste management sector. One of such wastes is silicon production waste [4]. Disposal and use of dusty waste of silicon production (microsilica) should be considered as an important area of material resources saving [5]. The use of waste allows companies to provide additional resources and reduce the environmental load [6,7,8]. Modern requirements for the reliability and strength of the well construction dictate the need to develop technologies and materials for its construction.

The cement ring located behind the casing string plays a significant role in the reliability of well construction.

During the final work on the construction of the well and its operation, the support receivessignificant loads that are constant, periodic, and short-term. The condition of the cement ring behind the casing string directly affects the tightness of the separation of productive and aquifer layers between them and the isolation of the casing strings from the negative influence of reservoir fluids.

Accordingly, the destruction of the plugging stone leads to the occurrence of intercolumn pressures, griffins, inter-layer overflows, and premature flooding of the formation. To improve the properties of the cementing slurry, a microsilica additive was proposed.

\section{Review of literature}

Despite the wide range of existing works on microsilica, they do not discuss the prospects of using silicon waste in the oil industry. The existing literature focuses on the production of metallic silicon, its state, and prospects [4,5]; the assessment of the environmental 
friendliness of the use of silicon production waste $[3,9,10]$; the experience of using microsilica additives from silicon production waste in concrete and construction technologies $[11,12,13]$. There are also works about possibilities and prospects for producing silumin with different silicon content using amorphous microsilica [14]; modification of fine-grained polymer concrete with microsilica [15]; high-performance concretes with modifying micro additives of microsilica and diopside [16]; development of cracking patterns in modified cement matrix with microsilica [17]; and the possibility of preparing alloys of the al-si system using amorphous microsilica [18]. The existing patents cover new ultra-high strength concrete [19], weighted grouting mortar [20], and highstrength fine-grained concrete [21].

\section{Development and optimization of the composition of grouting material}

Many articles have been written on increasing the resistance of the cement ring to dynamic loads. There are different approaches to solving this problem. Most scientists believe that Portland cement, despite all its advantages, has a significant drawback - as the strength of cement stone increases, its fragility also increases, and it is also characterized by low strength [12].

Therefore, a significant interest is directed to the improvement of expanding plugging systems for anchoring wells in the cryolithozone, which allows you to change such properties as strength, frost resistance, expansion, etc.

An additive based on silicon dioxide (microsilica) was proposed to increase the compressive and bending strength, the expansion factor of the grouting stone, frost resistance and reduce permeability.

Studies of the microsilica nanostructure show that the use of silicon dioxide nanoparticles leads to significant changes in the substance - significant compaction of cement stone and a corresponding improvement in its mechanical properties (an increase in compressive strength by 3-6 times). Besides, the modification of the material with silicon dioxide nanoparticles stabilizes the most important $\mathrm{Ca}-\mathrm{Si}-\mathrm{H}$ valence interactions, which are responsible for concrete connectivity, reducing calcium leaching, and increasing its moisture resistance $[22,23,24]$.

The development and optimization of the composition of the expanding plugging material took place in two stages. At the first stage, laboratory studies were conducted to study the effect of the amount of calcium oxide and microsilica on the density, setting time of the grouting solution, mechanical strength, the stone formed from it and its expansion at different water content.

The amount of calcium oxide added varied from 2,5 to $7.5 \%$ of the cement weight. During the preparation of the grouting solution, $\mathrm{CaO}$ was mixed with PCT - 1 - 50 Portland cement in dry form at different ratios. Fresh water and various concentrations of $\mathrm{CaCl}_{2}$ solution were used as the closing liquid. Sealing of the slurry was carried out in accordance with GOST 1581-96. The tests were carried out at a temperature of $20^{\circ} \mathrm{C}$.

Table 1. Composition of the grouting solution; properties of the grouting solution $(2,5-7,5 \% \mathrm{CaO})$.

\begin{tabular}{|c|c|c|c|c|c|c|c|c|c|}
\hline \multirow{2}{*}{ № } & \multicolumn{2}{|c|}{ Mixturecomposition } & \multirow{2}{*}{$\mathrm{CaCl}_{2, \%}$} & \multirow{2}{*}{$\begin{array}{l}\text { water- } \\
\text { cement } \\
\text { ratio }\end{array}$} & \multirow{2}{*}{$\begin{array}{c}\mathrm{P}, \\
\mathrm{kg} / \mathrm{m}\end{array}$} & \multirow{2}{*}{$\begin{array}{l}\text { Spreadability, } \\
\mathrm{m}\end{array}$} & \multicolumn{2}{|c|}{$\begin{array}{c}\text { Settingtime, } \\
\text { min }\end{array}$} & \multirow{2}{*}{$\begin{array}{l}\text { Extension } \\
\text { in } 3 \\
\text { days., \% }\end{array}$} \\
\hline & $\begin{array}{c}\text { PCT-1- } \\
50, \% \\
\end{array}$ & $\mathrm{CaO}, \%$ & & & & & start & end & \\
\hline 1 & 100 & - & - & 0.45 & 1900 & 0.19 & 380 & 410 & 0 \\
\hline 2 & 100 & - & 4 & 0.45 & 1920 & 0.15 & 125 & 140 & 0 \\
\hline
\end{tabular}




\begin{tabular}{|c|c|c|c|c|c|c|c|c|c|}
3 & 95 & 5 & - & 0.45 & 1900 & 0.20 & 415 & 455 & 0.10 \\
\hline 4 & 95 & 5 & 4 & 0.45 & 1930 & 0.14 & 30 & 75 & 0.11 \\
\hline 5 & 100 & - & - & 0.50 & 1860 & 0.22 & 410 & 490 & 0 \\
\hline 6 & 100 & - & 4 & 0.50 & 1870 & 0.17 & 160 & 185 & 0 \\
\hline 7 & 97.5 & 2.5 & - & 0.50 & 1860 & 0.25 & 430 & 510 & 0.07 \\
\hline 8 & 97.5 & 2.5 & 4 & 0.50 & 1880 & 0.16 & 120 & 170 & 0.08 \\
\hline 9 & 95 & 5 & - & 0.50 & 1850 & 0.24 & 430 & 450 & 0.11 \\
\hline 10 & 95 & 5 & 4 & 0.50 & 1880 & 0.10 & 110 & 150 & 0.12 \\
\hline 11 & 92.5 & 7.5 & - & 0.50 & 1860 & 0.25 & 365 & 485 & 0.16 \\
\hline 12 & 92.5 & 7.5 & 4 & 0.50 & 1880 & 0.13 & 80 & 110 & 0.18 \\
\hline 13 & 100 & - & - & 0.55 & 1810 & 0.26 & 515 & 585 & 0 \\
\hline 14 & 100 & - & 4 & 0.55 & 1820 & 0.22 & 120 & 180 & 0 \\
\hline 15 & 95 & 5 & - & 0.55 & 1810 & 0.25 & 480 & 540 & 0.14 \\
\hline 16 & 95 & 5 & 4 & 0.55 & 1820 & 0.22 & 120 & 160 & 0.14 \\
\hline 17 & 92.5 & 7.5 & - & 0.55 & 1800 & 0.26 & 465 & 610 & 0.18 \\
\hline 18 & 92.5 & 7.5 & 4 & 0.55 & 1810 & 0.21 & 95 & 115 & 0.18 \\
\hline
\end{tabular}

Table 2. Composition of the grouting solution, properties of the grouting solution $(2,5-7,5 \% \mathrm{CaO})$.

\begin{tabular}{|c|c|c|c|c|c|}
\hline \multirow{2}{*}{ № } & \multicolumn{2}{|c|}{ Mixturecomposition } & \multirow{2}{*}{$\mathrm{CaCl}_{2, \%}$} & \multirow{2}{*}{$\begin{array}{c}\text { Bending strength } \\
\text { after } 2 \text { days, } \\
\mathrm{MPa}\end{array}$} & \multirow{2}{*}{$\begin{array}{c}\text { Compressive strength after } 2 \\
\text { days, MPa }\end{array}$} \\
\hline & PCT-1-50, \% & $\mathrm{CaO}, \%$ & & & \\
\hline 1 & 100 & - & 6.1 & 20.5 & 1900 \\
\hline 2 & 100 & - & 5.0 & 27.1 & 1920 \\
\hline 3 & 95 & 5 & 3.6 & 14.9 & 1900 \\
\hline 4 & 95 & 5 & 6.1 & 32.5 & 1930 \\
\hline 5 & 100 & - & 3.8 & 11.9 & 1860 \\
\hline 6 & 100 & - & 4.4 & 19.1 & 1870 \\
\hline 7 & 97.5 & 2.5 & 3.9 & 11.1 & 1860 \\
\hline 8 & 97.5 & 2.5 & 4.5 & 19.7 & 1880 \\
\hline 9 & 95 & 5 & 3.1 & 10.9 & 1850 \\
\hline 10 & 95 & 5 & 4.8 & 19.1 & 1880 \\
\hline 11 & 92.5 & 7.5 & 2.9 & 10.1 & 1860 \\
\hline 12 & 92.5 & 7.5 & 4.9 & 21 & 1880 \\
\hline 13 & 100 & - & 2.8 & 8.5 & 1810 \\
\hline 14 & 100 & - & 3.2 & 13.8 & 1820 \\
\hline 15 & 95 & 5 & 2.3 & 9.1 & 1810 \\
\hline 16 & 95 & 5 & 3 & 15.1 & 1820 \\
\hline 17 & 92.5 & 7.5 & 2.6 & 7.4 & 1800 \\
\hline 18 & 92.5 & 7.5 & 3.1 & 13.9 & 1810 \\
\hline
\end{tabular}

The results of the study are shown in Tables 1,2. Analysis of the table shows that $\mathrm{CaO}$ additives from 2.5 to $7.5 \%$ have a slight effect on the setting time and strength of the cement, the largest expansion of the grouting stone was $0.19 \%$ (after three days of hardening). The best results are obtained by adding $4 \%$ calcium chloride to the grouting solution. However, taking into account the negative impact of the cryolithozone on the 
processes of hydration of the grouting material during cementing of wells in the Arctic, we recommended increasing the content of calcium oxide to $10-15 \%$.

Figure 1 and figure 2 show the dependence of the bending strength and expansion on the content of calcium oxide.

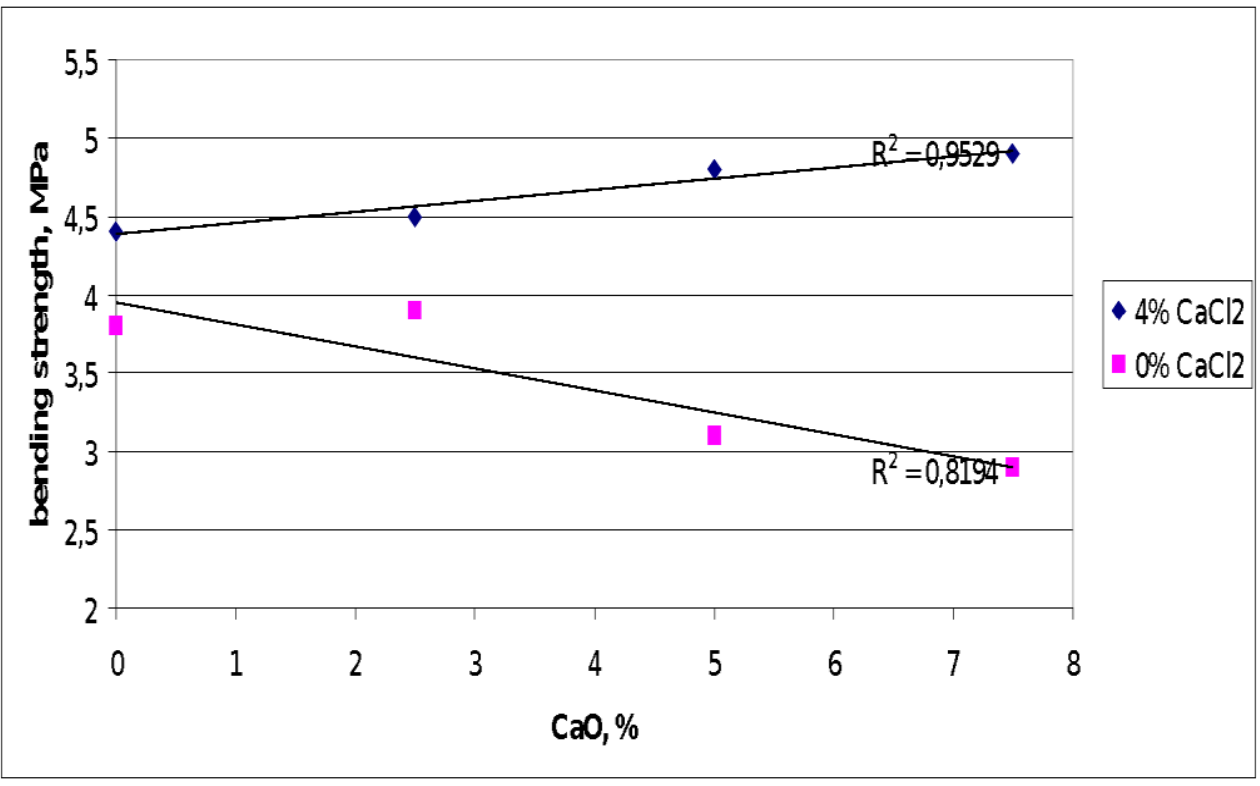

Fig. 1. Dependence of the bending strength of cement stone on the content of calcium oxide.

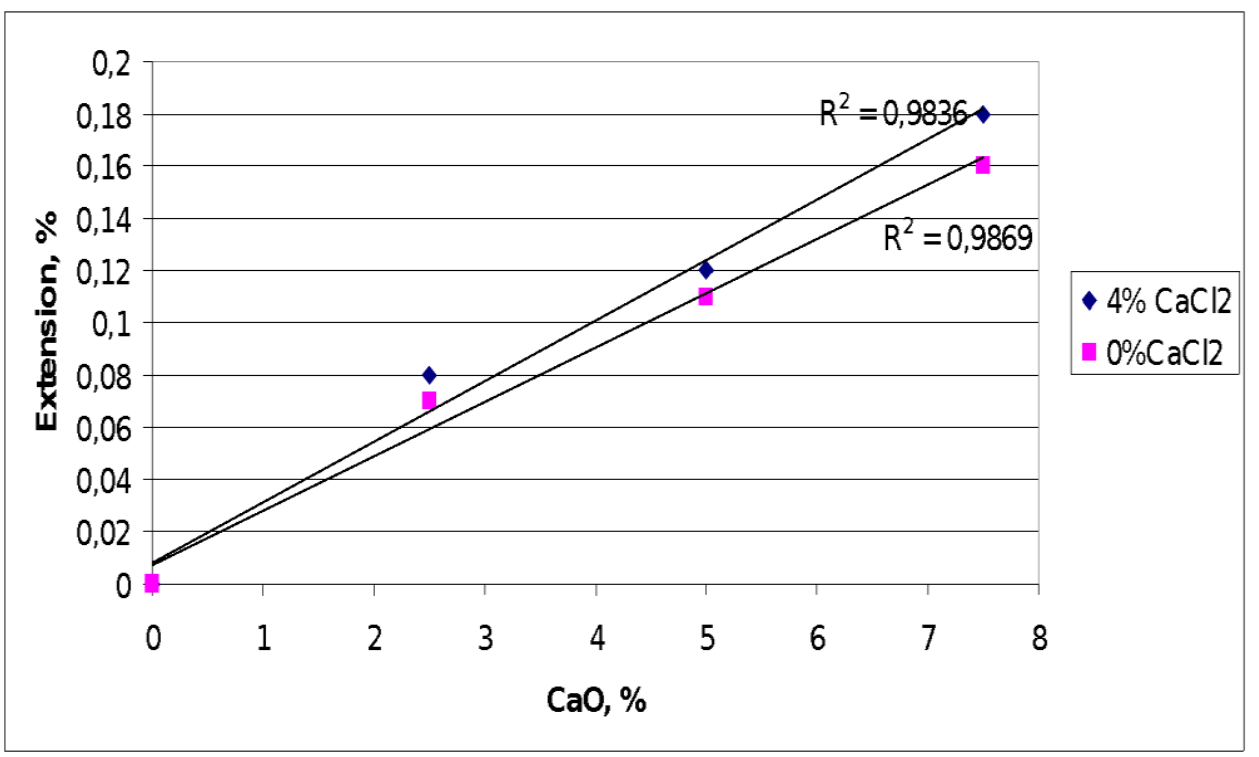

Fig. 2. Dependence of cement stone expansion on the content of calcium oxide.

At the second stage of the study, the influence of the amount of introduced microsilica $(10-15 \%)$ and calcium oxide $(8-15 \%)$ on density, setting time of grouting solution, 
strength and expansion of grouting stone formed from it was determined. The research results are listed in Tables $3-6$.

Table 3. Composition of the grouting solution, properties of the grouting solution (10-15 microsilica $\%, \mathrm{~T}=20^{\circ} \mathrm{C}$ ).

\begin{tabular}{|c|c|c|c|c|c|c|c|c|}
\hline & \multicolumn{4}{|c|}{ Composition of the grouting solution } & \multicolumn{3}{c|}{ Properties of the grouting solution } \\
№ & $\begin{array}{c}\text { PCT-1- } \\
50, \%\end{array}$ & Microsilica, \% & $\mathrm{CaO} \%$ & $\begin{array}{c}4 \% \\
\mathrm{CaCl}_{2}\end{array}$ & $\begin{array}{c}\rho, \\
\mathrm{kg} / \mathrm{m}^{3}\end{array}$ & $\begin{array}{c}\text { Spreadability, } \\
\mathrm{m}\end{array}$ & \multicolumn{2}{|c|}{$\begin{array}{c}\text { Settingtime, } \\
\text { min }\end{array}$} \\
& & & & & & & \\
start & end \\
2 & 80 & 10 & 10 & 0.6 & 1960 & 0.20 & 280 & 370 \\
3 & 75 & 10 & 15 & 0.6 & 1920 & 0.21 & 230 & 300 \\
4 & 75 & 15 & 10 & 0.7 & 1990 & 0.19 & 270 & 370 \\
\hline
\end{tabular}

Table 4.Composition of the grouting solution, properties of the grouting solution (10-15 microsilica $\%, \mathrm{~T}=20^{\circ} \mathrm{C}$ ).

\begin{tabular}{|c|c|c|c|c|c|c|c|c|c|c|}
\hline \multirow{3}{*}{ № } & \multicolumn{4}{|c|}{ Composition of the grouting solution } & \multicolumn{6}{|c|}{ Properties of the grouting solution } \\
\hline & \multirow{2}{*}{$\begin{array}{c}\text { PCT-1- } \\
50, \%\end{array}$} & \multirow{2}{*}{ Microsilica, $\%$} & \multirow{2}{*}{$\mathrm{CaO}, \%$} & \multirow{2}{*}{$\begin{array}{c}4 \% \\
\mathrm{CaCl}_{2}\end{array}$} & \multicolumn{3}{|c|}{$\begin{array}{c}\text { Strength of } \\
\text { cement stone, } \mathrm{MPa} \text {, } \\
\text { after }\end{array}$} & \multicolumn{3}{|c|}{ Extension, \%, after } \\
\hline & & & & & $\begin{array}{c}2 \\
\text { days }\end{array}$ & $\begin{array}{c}7 \\
\text { days }\end{array}$ & $\begin{array}{c}14 \\
\text { days }\end{array}$ & $\begin{array}{c}2 \\
\text { days }\end{array}$ & $\begin{array}{c}7 \\
\text { days }\end{array}$ & $\begin{array}{c}14 \\
\text { days }\end{array}$ \\
\hline 1 & 80 & 10 & 10 & 0.6 & 6.2 & 6.7 & 6.85 & 0.2 & 0.2 & 0.24 \\
\hline 2 & 75 & 10 & 15 & 0.6 & 5.7 & 6.1 & 6.31 & 0.2 & 0.3 & 0.34 \\
\hline 3 & 75 & 15 & 10 & 0.7 & 6.7 & 7.1 & 7.35 & 0.1 & 0.2 & 0.24 \\
\hline 4 & 70 & 15 & 15 & 0.7 & 6.1 & 6.5 & 6.69 & 0.2 & 0.2 & 0.29 \\
\hline
\end{tabular}

Table 5. Composition of the grouting solution, properties of the grouting solution (10-15 microsilica $\%, \mathrm{~T}=-2{ }^{\circ} \mathrm{C}$ ).

\begin{tabular}{|c|c|c|c|c|c|c|c|c|}
\hline \multirow{3}{*}{ № } & \multicolumn{4}{|c|}{ Composition of the grouting solution } & \multicolumn{4}{|c|}{ Properties of the grouting solution } \\
\hline & \multirow{2}{*}{$\begin{array}{l}\text { PCT-1- } \\
50, \%\end{array}$} & \multirow{2}{*}{ Microsilica, $\%$} & \multirow{2}{*}{$\mathrm{CaO}, \%$} & \multirow{2}{*}{$\begin{array}{c}4 \% \\
\mathrm{CaCl}_{2}\end{array}$} & \multirow{2}{*}{$\begin{array}{c}\rho, \\
\mathrm{kg} / \mathrm{m}^{3}\end{array}$} & \multirow{2}{*}{$\begin{array}{c}\text { Spreadability, } \\
\mathrm{m}\end{array}$} & \multicolumn{2}{|c|}{$\begin{array}{c}\text { Settingtime, } \\
\text { min }\end{array}$} \\
\hline & & & & & & & start & end \\
\hline 1 & 80 & 10 & 10 & 0.6 & 1960 & 0.20 & 360 & 440 \\
\hline 2 & 75 & 10 & 15 & 0.6 & 1920 & 0.21 & 410 & 455 \\
\hline 3 & 75 & 15 & 10 & 0.7 & 1990 & 0.19 & 390 & 470 \\
\hline 4 & 70 & 15 & 15 & 0.7 & 1930 & 0.21 & 275 & 320 \\
\hline
\end{tabular}

Table 6. Composition of the grouting solution, properties of the grouting solution (10-15 microsilica $\%, \mathrm{~T}=-2{ }^{\circ} \mathrm{C}$ ).

\begin{tabular}{|c|c|c|c|c|c|c|c|c|c|c|}
\hline \multirow{3}{*}{ № } & \multicolumn{4}{|c|}{ Composition of the grouting solution } & \multicolumn{6}{|c|}{ Properties of the grouting solution } \\
\hline & \multirow{2}{*}{$\begin{array}{c}\text { PCT-1- } \\
50, \%\end{array}$} & \multirow{2}{*}{ Microsilica, $\%$} & \multirow{2}{*}{$\mathrm{CaO}, \%$} & \multirow{2}{*}{$\begin{array}{c}4 \% \\
\mathrm{CaCl}_{2}\end{array}$} & \multicolumn{3}{|c|}{$\begin{array}{c}\text { Strength of } \\
\text { cement stone, MPa, } \\
\text { after }\end{array}$} & \multicolumn{3}{|c|}{ Extension, \%, after } \\
\hline & & & & & $\begin{array}{c}2 \\
\text { days }\end{array}$ & $\begin{array}{c}7 \\
\text { days }\end{array}$ & $\begin{array}{c}14 \\
\text { days }\end{array}$ & $\begin{array}{c}2 \\
\text { days }\end{array}$ & $\begin{array}{c}7 \\
\text { days }\end{array}$ & $\begin{array}{c}14 \\
\text { days }\end{array}$ \\
\hline 1 & 80 & 10 & 10 & 0.6 & 4.4 & 4.7 & 5.27 & 0.1 & 0.1 & 0.13 \\
\hline 2 & 75 & 10 & 15 & 0.6 & 4.0 & 4.3 & 4.85 & 0.1 & 0.1 & 0.15 \\
\hline
\end{tabular}




\begin{tabular}{|l|l|l|l|l|l|l|l|l|l|l|}
\hline 3 & 75 & 15 & 10 & 0.7 & 4.7 & 5.1 & 5.66 & 0.1 & 0.1 & 0.13 \\
4 & 70 & 15 & 15 & 0.7 & 4.3 & 4.6 & 5.13 & 0.1 & 0.1 & 0.15 \\
\hline
\end{tabular}

The analysis of the obtained results shows that the grouting mortar at the boundary values of silicon dioxide from 10 to $15 \%$, calcium oxide from 10 to $15 \%$, the water-hard ratio of $0.6-0.7$ has a density of $1920-1990 \mathrm{~kg} / \mathrm{m}^{3}$ and is characterized by a significant expansion of the stone formed from it, as well as an increase in strength.

At the same time, it was found that with an increase in the addition of microsilica, the expansion of the cement stone slightly decreased during the first three days and stabilized on days 7-14 days of hardening. At this stage, the cement stone has an expansion of 0.24 to $0.34 \%$ at a hardening temperature of $20{ }^{\circ} \mathrm{C}$ and 0.13 to $0.15 \%$ at a hardening temperature of minus $2{ }^{\circ} \mathrm{C}$.

An especially significant increase in the strength of cement stone is observed with the addition of microsilica in the amount of $10-15 \%$ of the weight of the binder. However, with an increase in the content of calcium oxide in the grouting mortar of more than $10 \%$, the bending strength of the stone significantly decreases, and if the content of silicon dioxide is more than $10 \%$, the expansion effect of the grouting stone decreases. The hardening temperature has a significant influence on the setting time, strength and expansion of the plugging stone.

The high strength helps maintain a constant density of the grouting solution over the entire height of the annulus space, unlike other systems. Cement slurry with additives microsilica is resistant to sedimentation. Cement stone with additives of silicon dioxide has low permeability.

The dependence of cement stone strength on microsilica contents at temperatures of $20{ }^{\circ} \mathrm{C}$ and $-2{ }^{\circ} \mathrm{C}$ can be observed in Figures 3 and 4, respectively.

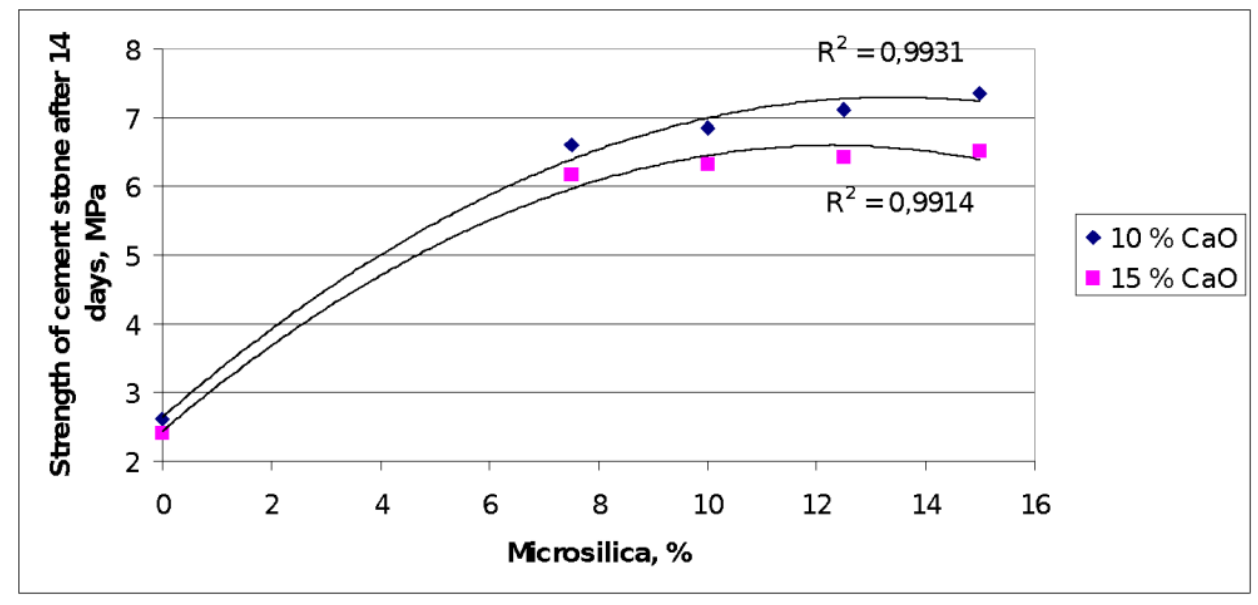

Fig. 3. Dependence of the strength of cement stone on the content of microsilica (at a temperature of $20^{\circ} \mathrm{C}$ ). 


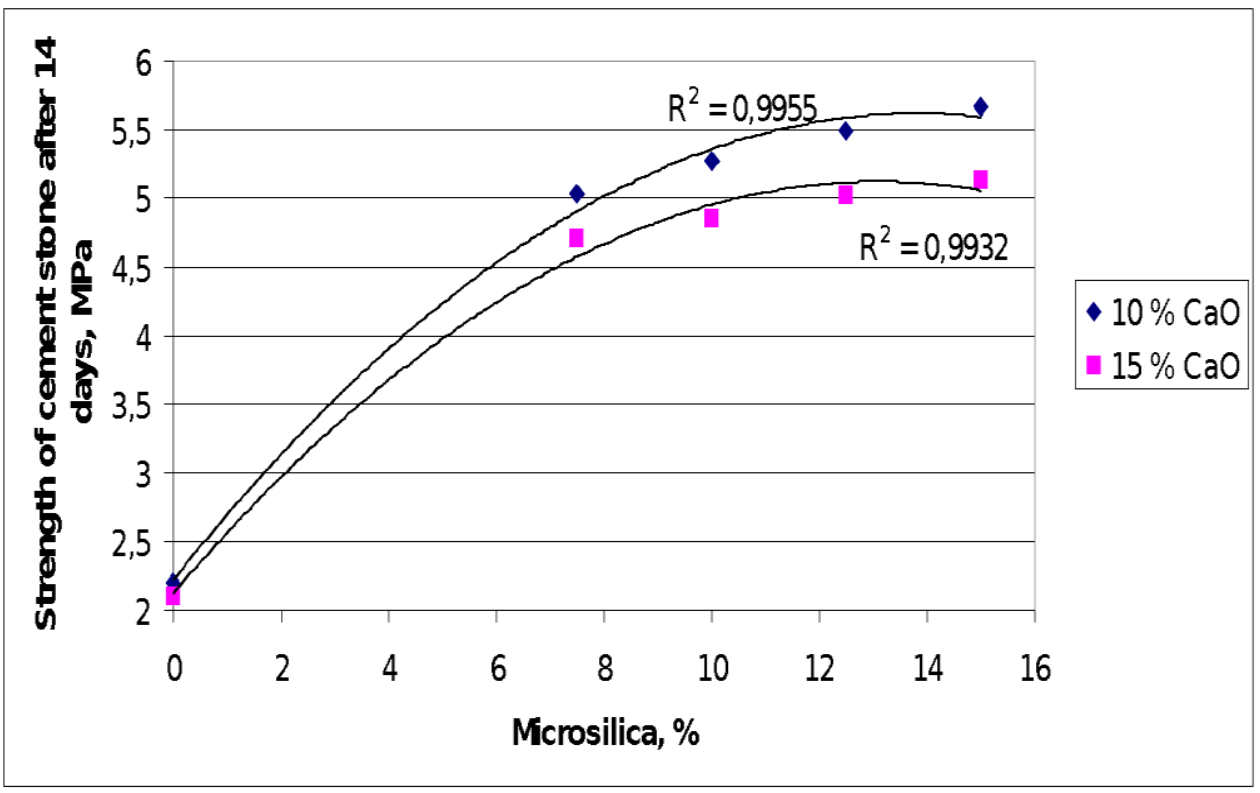

Fig. 4. Dependence of cement stone strength on the content of microsilica (at a temperature of $-2^{\circ} \mathrm{C}$ ).

\section{Conclusion}

It was found that the strength of Portland cement solutions increased with an increase in the content of microsilica additives from 3 to $15 \%$. However, it should be noted that with an increased amount of this additive (more than 15-20\%), cracking of samples may occur, and the frost resistance of cement stone is significantly reduced. When adding silicon dioxide, there also is an increase in the density and porosity of the cement stone, which, as a result, leads to an improvement in its water and corrosion resistance. Experiments have shown that the content of microsilica in Portland cement solutions in the amount of $6-12 \%$ has no negative impact on their properties, and this amount of additives can be considered optimal for achieving maximum strength of solutions.

The use of microsilica in the oil industry, namely in grouting solutions when cementing wells, improves the condition of the cement ring in the casing, the quality of cementing, increases the strength and tightness of the contact zones of the grouting stone, which allows to avoid various complications.

The authors express their gratitude and appreciation to the staff of the Departments of Metallurgy and Drilling of the Saint Petersburg Mining University for their attention, assistance and support at various stages of writing this article.

\section{References}

1. O. Cherermisina, M. Ponomareva, V. Bolotov, V. Alabusheva, S. KhaustovThe sorption process in the removal of sulfur components from industrial emissions. International Multidisciplinary Scientific Geo Conference, 19(1.3), 947-952 (SGEM. Sofia, 2019) 
2. V. M.Sizyakov, V. N. Brichkin About the role of hydrafed calcium carboaluminatesin improving the technology of complex processing of nephelines. JournalofMiningInstitute, 231, 292-298 (2018)

3. S. V.Zakharov, K. O.Vasiliev, E. V. Yermolovich Assessment of environmental friendliness of the use of silicon production waste.SB.: School of postgraduate students of the All-Russian scientific conference (Irkutsk, September, 2017), 16-20 (2017)

4. F. Bernd Microsilica- characterization of a unique additive. IIBCC 2006 - Sao Paulo, Brazil. October 15 - 18, 2006, (Universidade de Sao Paulo \& University of Idaho: Sao Paulo, 2006)

5. K. S. Elkin Production of metallic silicon in Russia - state and prospects. "Nonferrous metals and minerals 2014": materials of the sixth international congress (1619 September 2014),(Krasnoyarsk, 2014)

6. V.N. Brichkin, O. A. Dubovikov, N. V. Nikolayeva, A. A. Besedin Red mud dewatering and basic trends in its recycling. National Mineral Resources University (Mining University) (Russia), 1(349), 44-48 (2014)

7. V.N. Brichkin, V.V. Vasilyev, E.A. Nagornaya, A.M. Gumenyuk Bauxite grade improvement through selective grinding. JSC Polymetal Engineering, (2017)

8. A. B. Lebedev, V. A.Utkov, V. Yu. Bazhin Use of red mud as a modifier in granulation of metallurgical slags. The Bulletin of Irkutsk State University,1(144), 158-168 (2019)

9. M. V.Glazev, V. Y. Bazhin Environmental technologies in the production of metallurgical silicon. Scientificand Practical Studies of Raw Material Issues,0,114$120(2020)$

10. V. M. Sizyakov, E.V. Tikhonova, M.V. Cherkasova The efficiency of oxide magnesium compounds for purification of aluminous production liquors with organic impurity. Nonferrousmetal,9, 52-55 (2012)

11. O.M.Smirnova, M.V.Glazev, V.V.Komolov, M.Yu.Vilenskii Micro-Cement for Injection Consolidation of Base Soils.International Journal of Innovative Technology and Exploring Engineering (IJITEE), 9(2), 2173-2177 (2019)

12. K. N.Puzenko,V. B.Balabanov, D.Munchausen "experience with the use of additives, micro - and nanosilica from waste silicon production in concrete technology", proceedings of the universities. Investment. Construction. Realty.7(3(22)), (2017)

13. L. Ya.Ya.Trofimov, E. A.Gamalii, T. N.Chernykh, V. V.Zimich Cement Concrete and Mortar Modifiers (Specifications and Mechanism of Action), (Chelyabinsk: IskraProfi, 2012)

14. M.P.Kuz'min, M.Y.Kuz'mina, P.B. Kuz'min Possibilities and prospects for producing silumins with different silicon contents using amorphous microsilica. Transactions of non-ferrous metals society of China 2020,5(30), 1406-1418 (2020)

15. V. Balabanov, K. PutsenkoModification of fine-grained polymer concrete with microsilica. 2018 International scientific conference "Investment, construction, real estate: new technologies and special-purpose development priorities, ICRE 2018,(Irkutsk,2018)

16. L. Ilina, V. Rudyak, S. KhakimullinaHigh-performance concretes with modifying micro additives of microsilica and diopside. VII international symposium actual problems of computational simulation in civil engineering, APSCSE 2018, (Novosibirsk, 2018)

17. M. SzelagDevelopment of cracking patterns in modified cement matrix with microsilica. Materials,10(11), (2018) 
18. M.P.Kuz'min, V.V.Kondrat'ev, L.M.Larionov, M. Yu.Kuz'mina, N.N. Ivanchik Possibility of preparing alloys of the al-si system using amorphous microsilica.Metallurgist,1-2(61), 86-91 (2017)

19. F. Peres, L. Ferrejra, Zh.Vern, O. Alen New ultra-high strength concrete. Patent RU № 2693213 C2, (2019).

20. Belej I. I., Karmatskikh S. A.,Roder S. A. Weighted grouting mortar. Patent RU $2717854 C 1,(2020)$

21. M. E. Skorkin, G. G. Ryabov, R. G. Ryabov High-strength fine-grained concrete. Patent RU 2641813 C2, (2018)

22. I. Richardson Tobermorite/jennite- and tobermorite/calcium hydroxide-based models for the structure of C-S-H: Applicability to hardened pastes of tricalcium silicate, beta-dicalcium silicate, Portland cement, and blends of Portland cement with blastfurnace slag, metakaolin, or silica fume. Cem. Concr. Res.,34, 1733-1777 (2004)

23. M. Heikal, H. El-Didamony, T. M.Sokkary, I. A. Ahmed Behavior of composite cement pastes containing microsilica and fly ash at elevated temperature. Constr. Build. Mater.,38, 1180-1190 (2013)

24. M. Szelag The influence of microsilica on the cluster cracks' geometry of cement paste. In Proceedings of the 18th International Conference on Civil Engineering and Building Materials, Rome, Italy, 8-9 December 2016. 